\title{
Free Mobility with the EU and Immigration of North American Brains to Switzerland: What Consequences?
}

\author{
Dominique M. Gross ${ }^{a}$
}

JEL-Classification: F22, J21, J61.

Keywords: High-skill immigration, free mobility policy, Switzerland, North America, incentives.

\section{Introduction}

In this paper, I investigate the factors that drive North American brains to Switzerland before and after the implementation of the free mobility agreement with the European Union in 2002. The analysis is about immigrants in occupation categories requiring high education levels who came from Canada and the United States between 1990 and 2009. The main question is: Has the free mobility agreement led to substitution away from North American brains ${ }^{1}$ and did it change factors influencing non-European high-skill workers to come to Switzerland? The focus of the paper is the impact of the new policy on immigration flows from North America in terms of magnitude and incentives; some potential consequences for Swiss firms' competitiveness on the world market are then discussed.

After a decade of increasing free mobility with the European Union, there are mixed reactions in the Swiss society about the perceived impact of the policy especially on high-skill expatriates. Some argue that not only foreign university professors are taking jobs of Swiss citizens but the diversity of foreign academics' origins is extremely low. Muller (2010), p.78, for example, states: "The Swiss People's Party [...], a right-wing group notorious for its nationalist politics, accused the University of Zurich of having too many German nationals on its faculty." Others, the business sector in particular, hold opposite views. When

a Professor, School of Public Policy, Simon Fraser University, Harbour Centre, 515 West Hastings St., Vancouver, V6B 5K3, Canada.

I thank Kemi Alfolabi and Andriy Baransky for their invaluable assistance in compiling the dataset, seminar participants at the University of Neuchâtel and a referee, for their comments. I also thank the School of Economics at the University of New South Wales, Sydney, Australia, for its hospitality while writing this paper.

1 High-skill immigrants/expatriates/workers and brains are used interchangeably in this paper. 
asked whether skilled labor was readily available, business executives estimated that Switzerland was performing less well in 2010 than in 2002. In 2010, the index value was 7.01 on a scale to 10 compared to 7.25 in 2002 (IMD, 2010). Executives appear to blame the new immigration policy as the perception that immigration legislation prevented companies to employ foreigners has risen from 5.56 in 2002 to 7.55 in $2010 .^{2}$ Yet, when asked whether foreign high-skill people were attracted to their country's business environment, executives evaluated Switzerland at 9.12 in 2010 compared to 7.95 in 2002. So it appears that according to business executives Switzerland has become more attractive to high-skill immigrants but, hiring them has become more difficult despite the introduction of free mobility with the EU. These perceptions have been confirmed by an observed shortage of highly educated professionals and calls for easier immigration procedures for highly skilled individuals from non EU/EFTA countries (Swiss American Chamber of Commerce and Boston Consulting Group, 2008, pp. 54-55).

Such divergences in opinions raise questions about the actual impact of the introduction of free mobility with EU countries on access to high-skill immigrants from other countries of the world. When skills are internationalised, substitution among brains from various origins may not appear to have costly consequences for the receiving economy. However, there are potential economic costs beyond the nationalistic argument against homogenous ethnic origins made by the Swiss People Party. Growing research shows that ethnic skilled diaspora contribute through several channels to the economic development of their host country. Skilled expatriates influence positively trade (see RAUCH, 2001, for a survey) and they can also affect positively foreign direct investment (see, for example, Buch, Kleinert and Toubal, 2006; Javorcik et al., 2011). Also, in a recent paper, Foley and Kerr (2011) show that, skilled immigrants can improve the world competitiveness of their host country's firms wanting to enter foreign markets. The argument behind the functioning of all three channels is easier access through better information thanks to expatriates' networks. Hence, in the long run, by having to give priority to EU citizens Swiss firms clearly strengthen their access to the EU market but may miss on opportunities to build competitive advantage in other foreign markets.

In this study the rest of the world is represented by Canada and the United States and the results show that the introduction of free mobility with the EU in 2002 has had a substantial negative effect on skilled immigrant flows from

2 It is worth noting that the perception about brain drain hindering competitiveness has been constant since the introduction of free mobility (7.43 in 2002 versus 7.5 in 2010), suggesting the degree of Swiss brains' exodus has hardly change. 
those two countries. The impact was not limited to a time-specific drop as the role of some factors influencing immigration changed significantly. Since 2002, North American highly skilled people are more influenced by a stimulating work environment at home and there has been a clear substitution away from them, in favour of Europeans and Swiss. In addition employers must now offer attractive financial conditions to North American high-skill candidates. So not only do Swiss employers have limited access to North American brains but they face stiffer competition to attract them. Finally, in addition to the adverse effects of the new policy, a negative trend in hiring of North American innovators due to labour market conditions might in the future diminish Swiss firms' competitiveness on world markets.

The rest of the paper is organized in the following way: Section 2 presents a brief survey of Swiss immigration policy since the mid-1990s. Section 3 describes changes in the composition of immigration to Switzerland since the implementation of free mobility. In Section 4, a model of skilled immigration from Canada and the United States is estimated to evaluate the nature and magnitude of substitution between North American and European brains and economic implications are discussed. Section 5 concludes.

\section{Swiss Immigration Policy}

Swiss immigration policy experienced little change between the early 1970s and the late 1990s but the approval by popular vote of free mobility with the EU/EFTA in 2000 led to drastic changes to the law for citizens coming from third countries. ${ }^{3}$ Swiss policy has always been demand-driven and thus requires foreigners obtain a one-year or longer job contract prior to applying for a "permanent" work/residence permit. ${ }^{4}$ Another avenue, until 2002, was through conversion of temporary status (i.e., seasonal permits). Generally one-year permits (i.e., sojourn permit) were automatically renewed conditional on employment. After a certain number of years of residence with such permits, immigrants and their family could apply for an unlimited, unconstrained permit (i.e., establishment permit). Yearly annual quotas were set for the number of new sojourn permits, not including seasonal conversions.

3 For a detailed history of immigration policy in Switzerland and its impact on the foreign resident population, see Gross (2006).

4 The word "permanent residents" covers foreigners residing in Switzerland for a period of one year or longer (OFS, 2009, p. 5). This definition is different from the one used by settlement countries such as Canada and the United States where only people with unlimited authorizations are considered permanent. 
Until the mid-1990s, there was no defined priority for the hiring of foreign workers. In 1995, the government developed the new circle-policy with priority given to citizens of countries similar in culture to Switzerland. Also, anticipating on the signing of an agreement with the EU, in November 1998, the government introduced the dual recruiting system by advising employers to give preferences to workers from the European Union; they could however, still prospect worldwide for skilled workers.

Following approval by popular vote in 2000, the implementation of the free mobility agreement with the EU/EFTA countries started on June $1^{\text {st }}, 2002$ and a new immigration legislation was in place by December $2005 .^{5}$ The most relevant component of the new legislation for this study is the specification of search priorities for employers who want to hire foreign workers: Third countries' citizens can be considered only if they are skilled and no worker is available on the domestic or EU/EFTA labor markets. Hence, priority must be given to Swiss citizens, foreigners living in Switzerland with permanent status and residents in EU/EFTA countries. Employers must prove they have searched extensively before submitting a request for hiring from third countries. Furthermore, only skilled candidates (i.e., managers, specialists and workers with tertiary education) can be considered with a few exceptions, i.e., in case of intra-firm transfers or exchanges, acute shortages of labor in economically key occupations, or firm's creation leading to local employment growth. The conditions may also be relaxed to gain access to new markets, expand exports or for non economic activities such as arts, culture, religion and international organisations. Once their hiring has been approved, third-country citizens receive a sojourn permit (livret B) valid for one year, renewable. They are eligible for an establishment permit generally after ten years, in some cases after five.

From 2002, there was a five year transitory period with quotas before implementation of complete free mobility. Initially, the agreement concerned only 15 EU member countries and the EFTA countries. On June $1^{\text {st }}, 2004$ it was extended to the ten new EU members. ${ }^{6}$ By June $1^{\text {st }}, 2007$, the transition period was completed for the initial 15 countries plus Cyprus and Malta, and complete free mobility applied to their citizens. Since May $1^{\text {st }} 2011$, it applies to the remaining

5 See DFJP \& ODM (2011a, 2011b) for brief descriptions and ConfÉdération Suisse (2011a, 2011b) for the original documents. From 2002 a government order was in place until 2005.

6 EU-15 includes Austria, Belgium, Denmark, Finland, France, Germany, Greece, Ireland, Italy, Luxemburg, the Netherlands, Portugal, Spain, Sweden, and the UK. In 2004, 10 countries joined the EU, Cyprus, Czech Republic, Estonia, Hungary, Latvia, Lithuania, Malta, Poland, Slovakia and Slovenia. EFTA members are Iceland, Liechtenstein and Norway in addition to Switzerland. 
eight members who entered in 2004. The latest step in the process has been the start of the transitory period for Bulgaria and Romania on June, $1^{\text {st }}$, 2009. By 2014, all EU/EFTA countries are expected to benefit from full free mobility with Switzerland. It must be noted that free mobility does not exempt foreign citizens from applying for permits. Their sojourn permit (livret $B$ ) is valid for five years after which period they can apply for an establishment permit. To obtain a sojourn permit they must be employed, show proof of independent activity or if inactive, have financial resources and health insurance coverage.

The major change that is likely to have affected brain flows from third countries is priorities imposed on employers for hiring. Non-European skilled individuals are still eligible for immigration to Switzerland but only after potential candidates in Switzerland and the EU countries have been considered. Such regulation is expected to lead to substitution among skilled immigrants from various geographical areas. The remaining of this paper provides a descriptive and econometric analysis to identify whether the new legislation has actually led to substitution away from North American brains in favor of European and Swiss ones after 2002.

\section{Brain Immigration to Switzerland}

The choice of Canada and the United States (US) to represent third countries is guided by the fact that the two countries have historically provided the most educated immigrants to Switzerland. In 2000, 49.7\% of Canadian and 57.6\% of American expatriates in Switzerland had tertiary education. Only immigrants from the United Kingdom and Sweden had a comparable levels of education with $50.1 \%$ and $52.2 \%$ respectively (Docquier and Marfouk, 2005). Also, their education standards are relatively similar to those of Europe and Switzerland which is likely to have made it easier for employers to follow the new legislation and substitute away from them in favour of Europeans and Swiss skilled workers.

The legislation targets new immigrant workers and Figure 1 shows the evolution of the inflows of workers (total and skilled) from Canada and the United States from 1990 to $2010 .^{7}$ Not surprisingly at the beginning of the $21^{\text {st }}$ century, there is a sharp drop in the total annual number of North Americans coming to Switzerland. In 2003, after nineteen months of implementation of

7 In Figure 1, skilled is defined according to the International Standard Classification of Occupation (ISCO) from the International Labour Office (ILO) and includes legislators, senior officials and managers (ISCO-1), professionals (ISCO-2) and technicians and associate professionals, (ISCO-3; ILO, 1990). 
the free mobility treaty with the EU/EFTA, the yearly number of Canadians migrating to Switzerland had fallen by $61.1 \%$ and that of Americans, by $52.2 \%$ (Table 1, column 6). The restrictions on hiring also affected skilled immigration yet slightly less drastically. By 2003, the annual flow of skilled Canadians had dropped by $49.1 \%$ and that of Americans, by $49.7 \%$ (Table 2, column 2). Note that some other non-European industrialised countries have experienced even sharper declines; the annual skilled flow from Australia and New-Zealand dropped by $51.8 \%$ and $71.4 \%$ respectively between 2001 and 2003 . The flow from Japan also fell but less with $-20.5 \%$.

Between 2001 and 2003 other factors than the introduction of the new legislation may have affected North American immigration to Switzerland as overall immigration decreased by $15.5 \%$ and that from EU15 by $11.6 \%$ (Table 1 , column 6). However, by 2010, the inflow from EU15 countries, had grown back and passed the 2001-level by about $70 \%$. The recovery has been most spectacular for Germany as total annual immigration in 2010 was $90.4 \%$ above the 2001 level. France and Italy experienced slightly smaller increases. As a result, the share of EU15 in total immigration rose from 63.7\% in 2001 to 85\% in 2010 (ODM, various years). In contrast, by 2010 , immigration from the US was about $2 / 3$ of its peak 2001-level and immigration from Canada was only about $1 / 3$ of it. Similarly, by 2010, the flow from Australia and New-Zealand represented only $46.5 \%$ and $65.1 \%$ of their $2001-$ levels. ${ }^{8}$

The sharp falls in the early 2000s followed a long period of steady increases especially in North American immigration. From 1994, a year before the introduction of the circle policy, until 2001 the total annual inflow of immigrants from Canada and the United States rose by $110.7 \%$ and $31.8 \%$ respectively (Table 1, column 5). During that period, immigration from EU15 countries grew only by $8.2 \%$. However, when only skilled workers are considered in Table 2 , column 1, the growth rates for European countries are much larger than for total immigration while they are close for North America. Hence, before free mobility at the end of the $20^{\text {th }}$ century, the skill intensity of European migrants to Switzerland was growing quite fast while that of North American, already the highest, was constant.

Generally, the government's recommendation to give priority to European workers at the end of 1998 (i.e., dual recruiting) does not appear to have had

8 Unfortunately Australia and New-Zealand cannot be included in the analysis because no occupation specific data is available for the estimations. However, the facts presented in this Section suggest that the results from this study are likely to be relevant for those two AngloSaxon countries. 
Figure 1: Immigration Flows of Americans and Canadians to Switzerland

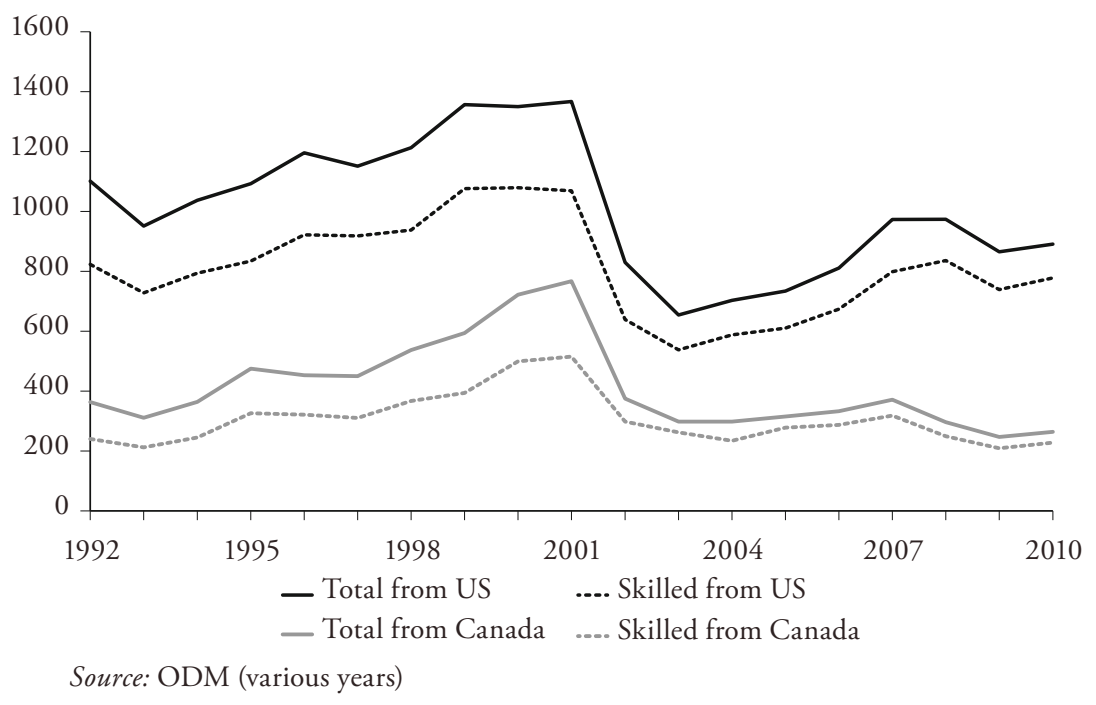

Table 1: Total Annual Immigration Flows from North America and Selected EU Countries

\begin{tabular}{|c|c|c|c|c|c|c|c|}
\hline & $\begin{array}{c}1 . \\
1994\end{array}$ & 2001 & $\begin{array}{c}3 . \\
2003\end{array}$ & $\begin{array}{c}4 . \\
2010\end{array}$ & $\begin{array}{c}5 . \\
\% \text { change } \\
1994- \\
2001\end{array}$ & $\begin{array}{c}6 . \\
\% \text { change } \\
2001- \\
2003\end{array}$ & $\begin{array}{c}7 . \\
\% \text { change } \\
2001- \\
2010\end{array}$ \\
\hline Total & 40,331 & 41,867 & 35,396 & 53,193 & 3.8 & -15.5 & 27.1 \\
\hline Canada & 364 & 767 & 298 & 264 & 110.7 & -61.1 & -65.6 \\
\hline United States & 1,037 & 1,367 & 654 & 891 & 31.8 & -52.2 & -34.8 \\
\hline EU15 & 24,651 & 26,681 & 23,574 & 45,235 & 8.2 & -11.6 & 69.5 \\
\hline Austria & 1,010 & 1,704 & 927 & 1,541 & 68.7 & -45.6 & -9.6 \\
\hline France & 2,849 & 3,774 & 2,640 & 6,416 & 32.5 & -30.0 & 70.0 \\
\hline Germany & 4,727 & 9,892 & 7,132 & 18,830 & 109.3 & -27.9 & 90.4 \\
\hline Italy & 4,031 & 2,982 & 1,846 & 5,664 & -26.0 & -38.1 & 89.9 \\
\hline
\end{tabular}

Source: ODM (various years) 
Table 2: Skilled Immigration from North America and Selected EU Countries

\begin{tabular}{|c|c|c|c|c|c|c|c|}
\hline & \multicolumn{3}{|c|}{ Growth skilled flows ${ }^{a}$} & \multicolumn{4}{|c|}{ Share of skilled immigrant workers } \\
\hline & $\begin{array}{c}1 . \\
\% \text { change }\end{array}$ & $\begin{array}{c}2 . \\
\% \text { change }\end{array}$ & $\begin{array}{c}3 . \\
\% \text { change }\end{array}$ & 4. & 5. & 6. & 7. \\
\hline & $\begin{array}{c}1994- \\
2001\end{array}$ & $\begin{array}{c}2001- \\
2003\end{array}$ & $\begin{array}{c}2001- \\
2010\end{array}$ & 1994 & 2001 & 2003 & 2010 \\
\hline Canada & 110.2 & -49.1 & -55.7 & 67.3 & 67.1 & 87.9 & 86.4 \\
\hline United States & 34.6 & -49.7 & -16.7 & 76.6 & 78.2 & 82.3 & 87.3 \\
\hline Austria & 137.1 & -40.3 & -14.8 & 31.8 & 44.7 & 49.0 & 42.1 \\
\hline France & 77.6 & -29.2 & 33.3 & 43.0 & 57.7 & 58.4 & 45.2 \\
\hline Germany & 134.5 & -30.6 & 20.3 & 61.0 & 68.4 & 65.8 & 43.2 \\
\hline Italy & 28.5 & -33.1 & 75.6 & 19.7 & 34.2 & 37.0 & 31.6 \\
\hline
\end{tabular}

a Skilled is defined according to the ILO International Standard Classification of Occupation (ISCO) and includes legislators, senior officials and managers (ISCO-1), professionals (ISCO-

2) and, technicians and associate professionals, (ISCO-3; ILO, 1990).

Source: ODM (various years)

much of an impact on employers' hiring strategies. However, when the recommendation became law in 2002, the flows from many countries and North America in particular were reduced drastically and remained low throughout the decade. So, it is likely that substitution occurred in favour of European countries since the drop in North American immigration was permanent.

Consistent with the new legislation, the shift in the origin of foreign workers has been accompanied by a shift in the skill composition: By 2010 the shares of high-skill immigrants in total were $86.4 \%$ for Canadians and $87.3 \%$ for Americans up from an average of $68.3 \%$ and $78.1 \%$ respectively between 1994 and 2001 (Table 2, column 7). Thus, North American immigration to Switzerland which had been historically high in skill content became even more skill intensive after the introduction of free mobility with the EU. Since employers could hire low-skill workers only from EU countries, it is not surprising that these countries have experienced a fall in skill intensity since 2001 after the 1990s' rise. France and Germany show the largest falls: -12.5 and -25.2 percentage points respectively (Table 2, columns 5 and 7).'

9 It is worth noting that Germany is the only border country for which the share of high-skill immigrants in 2010 is not only lower than in 2001 but also lower than in 1994 (43.2\% in 2010 versus $68.4 \%$ in 2001 and $61 \%$ in 1994). 
In short, North Americans coming to Switzerland are now more educated but their number has dropped drastically compared to Europeans. Next the econometric analysis focuses on identifying the impact of the change in legislation on standard factors driving immigrants and possible implications for the future of the Swiss economy are discussed.

\section{What Drives North American Brains to Switzerland?}

For this analysis, skilled immigrants are classified in eleven occupation categories based on ILO-ISCO. They cover managers (F), professionals (A, C, D, E, H, I, J, L) and technicians (G, B; see Appendix I, Table A.I.1. for details). Table 3 shows the levels of occupation flows from Canada and the United States to Switzerland during nine years before (1993-2001) and nine years after (2002-2010) the start of the implementation of the free mobility agreement. The total flows from the two countries fell by about the same magnitude between the two periods $(-31.3 \%$ from Canada; $-31.8 \%$ from the US) and there are similarities as well as differences between occupation categories.

For both countries the maximum positive change occurred for managers $(+89.4 \%$ from Canada; $+73.9 \%$ from the US); a result which is not surprising since managers' migration is likely to result from intra-firm transfers that are exempted from the hiring priority rule set by the new legislation. Also, American companies have long found Switzerland attractive for establishing regional or world headquarters. ${ }^{10}$ The only other occupation categories with positive growth are Canadian engineers $(\mathrm{E} ;+42.9 \%)$ and American architects and related specialists $(\mathrm{A} ;+14.3 \%)$. A major difference between the two countries is the magnitudes of the drops across occupation categories. Three categories from Canada experienced more than fifty percent decline (commercial and financial technicians, $-60.6 \%$, teachers, $-62.6 \%$, and scientists, $-51.3 \%$ ) while five from the US did so (social scientists and humanities related professionals, $-75.7 \%$, health and science technicians, $-73.0 \%$, teachers, $-69.9 \%$, scientists, $-68.1 \%$, and commercial and financial technicians, $-62.6 \%)$. Finally, the flow of academics declined but relatively modestly, i.e., $-21.0 \%$ from Canada and $-7.0 \%$ from the United States.

10 According to OSEC Business Network, Swiss American Chamber of Commerce and McKinsey \& Company (2008), p. 7, in 2008, 150 US companies were present in Switzerland against only ten Asian companies. See also Arthur D. Little (Switzerland) Ltd (2009). 
Table 3: North American Annual Average Flows of Skilled Immigrants per Occupation Categories (1990-2000; 2002-2010) ${ }^{\mathrm{a}}$

\begin{tabular}{lrrr|rrr}
\hline & \multicolumn{3}{c|}{ From Canada } & \multicolumn{3}{c}{ From the United States } \\
Occupation categories & $1993-$ & $2002-$ & $\%$ & $1993-$ & $2002-$ & $\%$ \\
& 2001 & 2010 & change & 2001 & 2010 & change \\
\hline Total & 3,496 & 2,402 & -31.3 & 9,212 & 6,278 & -31.8 \\
\hline A Architects and related specialists & 9 & 9 & 0.0 & 21 & 24 & +14.3 \\
B Commercial and financial & 378 & 149 & -60.6 & 1,224 & 458 & -62.6 \\
$\quad$ technicians & & & & & & \\
C Teachers & 703 & 263 & -62.6 & 1,623 & 488 & -69.9 \\
\hline D Physicians & 38 & 30 & -21.1 & 77 & 48 & -37.7 \\
\hline E Engineers & 63 & 90 & +42.9 & 241 & 228 & -5.4 \\
F Managers & 407 & 771 & +89.4 & 2,141 & 3,724 & +73.9 \\
\hline G Health and science technicians & 1,313 & 739 & -43.7 & 1,047 & 283 & -73.0 \\
\hline H Social scientists and humanities & 346 & 188 & -45.7 & 2,097 & 510 & -75.7 \\
$\quad$ related professionals & & & & & & \\
\hline I IT professionals & 138 & 95 & -31.2 & 419 & 298 & -28.9 \\
\hline J Scientists & 39 & 19 & -51.3 & 135 & 43 & -68.1 \\
\hline L Academics & 62 & 49 & -21.0 & 187 & 174 & -7.0 \\
\hline
\end{tabular}

a From March to June 2008, a much larger proportion of immigrants did not declare an occupation (between $14 \%$ and $31 \%$ instead of about $2 \%$ ) and thus the 2008 -flow is slightly underestimated. In 2008, the share of workers not declaring an occupation was $12.7 \%$ against $11.7 \%$ in the preceding year. So, the overall effect on total worker immigration is negligible and it is likely to be even smaller on skill- and country-specific flows.

Sources: see Appendix I for category definitions; ODM (various years).

The consequence of these changes has been a re-distribution of the categories' shares between the two periods (Figure 2). Managers now dominate the skilled immigrant flows from North America $59.3 \%$ for the US in the $21^{\text {st }}$ century; $32.1 \%$ for Canada). But the flows from Canada remain more diversified than those from the US. No other occupation category represents more than $10 \%$ of skilled immigration from the United States, while from Canada health and science technicians $(G)$ represent almost the same share as managers $(30.8 \%$ vs. $32.1 \%)$. For both countries architects and related specialists (A) engineers (E), IT professionals (I) and academics (L) saw their share increase slightly. In short, the drop in immigration was not uniform. 
Figure 2: Share of Each Occupation Group Before and After Free Mobilitv

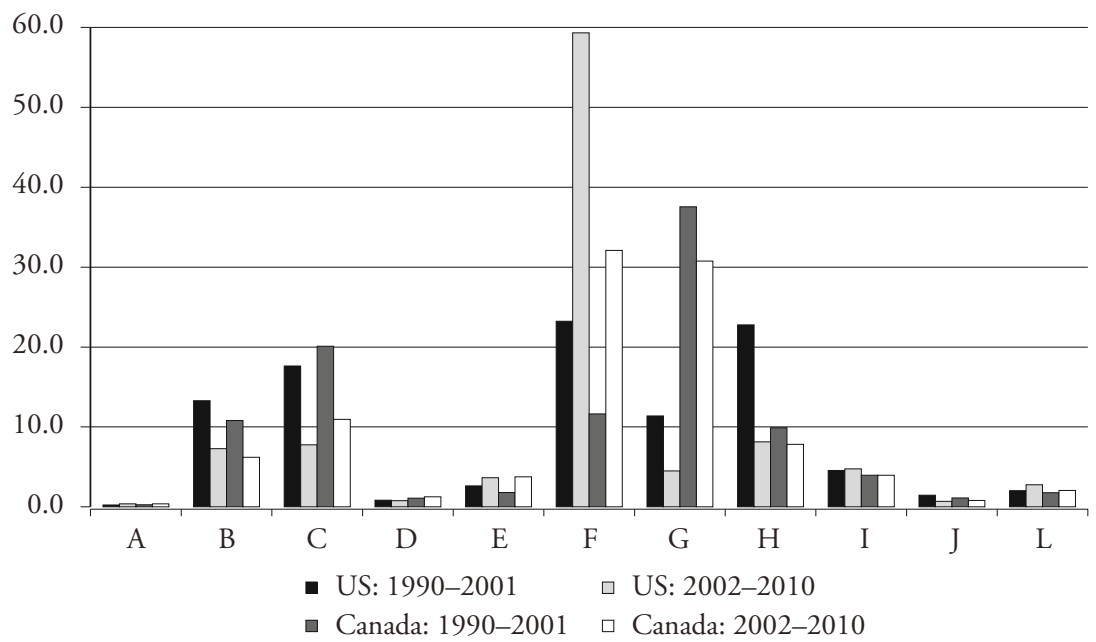

Source: ODM (various years)

\subsection{Background Model and Empirical Implementation}

Aside from the literature on brain drain which tends to focus on the impact of skilled migration on source countries' welfare (see for example, IVLEvs and DE Melo, 2008; Commander, Kangasniemi, and Winters, 2004; Beine, DocQUIER, and RAPOPORT, 2001), few studies focus on international migration of the highly skilled. ${ }^{11}$ There is however a growing literature on the location decision by high-skill migrants to which this paper is a contribution because understanding what drives skilled migrants to move among rich countries is fundamental to designing policies to attract them. The basic theoretical framework to analyze such flows is the standard push/pull model that originates in internal migration,

11 Modeling the flows of skilled workers from North America to Switzerland in the context of brain drain would be difficult to justify the main reason being that the Swiss labor market, while attractive, is very small. Between 1990 and 2000, the rate of skilled emigration (defined as the number of emigrants per 100,000 skilled member of the labor force in the source country) of Canadians to the US was more than ten times larger than that of Canadians to Switzerland (2,867 versus 227); the rate for the Swiss going to the United States was 445 while the rate of the Americans coming to Switzerland was 35 (Gross, 2011). 
where workers maximize returns to labor (SJAASTAD, 1962; Harris and TodAro, 1970; BorJas, 1987). Given, the questions investigated in this study, the analytical framework must be able to accommodate individual choices, i.e. supplyside, as well as policy issues, i.e., demand-side and the push/pull model has been recently developed in that direction. For example, Clark, Hatton, and WiLLIAMSON (2007) combine BorJas (1987)'s model of migration driven by human capital return with various immigration policies implemented by the US. A commonly used empirical specification for migration flows consistent with the individual's utility maximizing present value decision and flexible enough to accommodate policy factors is the gravity model, ${ }^{12}$ the general equation of which is,

$$
F l_{j k}=\frac{G_{j k}\left[w_{j}\left(M_{j}^{\alpha}\right) w_{k}\left(M_{k}^{\beta}\right)\right]}{d_{j k}^{b}},
$$

with $F l_{j k}$ the flow between country $j$ and $k$ which is a function of weighted mass $(w M)$ in each country and distance between the two countries $(d)$. The weighted mass in the case of skilled migration is educated population corrected by the standard of living (ISARD, 1998); distance can be physical, cultural, political or professional, depending on the case under investigation. A log linear specification of (1) is thus:

$$
\begin{aligned}
& \text { IFlRate }_{j i t}^{C H}=c_{j i}+\beta_{1} \text { IEarn }_{i t}^{C H}+\beta_{2} \text { IEearn }_{j i t}+\beta_{3} U R U n i_{t}^{C H}+\beta_{4} U R U n i_{j t} \\
& +\beta_{5} l L F U n i_{t}^{C H}+\beta_{6} l L F U n i_{j t}+\text { Policy } 2002+\varepsilon_{j i t} .
\end{aligned}
$$

The dependent variable (IFlRate $\left.{ }_{j i t}{ }_{j i}\right)$ is the log of immigration rate of skilled individuals in occupation $i$ ( $i=1$ to 11 ), from country $j$ ( $j=$ Canada, US) to Switzerland $(C H)$, during year $t(t=1990$ to 2009). The model is estimated over 440 observations. The fixed effect $\left(c_{j i}\right)$ accounts for time-invariant, source country-specific and occupation-specific factors.

Immigration rate is the annual inflow from Canada and the United States of skilled people as a share of the Swiss university-trained labor force in thousands during the previous year. ${ }^{13}$ Destination rather than source labor force is used for standardization to ensure consistency across panels and the previous year

12 See for example, Helliwell (1997), Karemera, Oguledo, and Davis (2000), Lewer and VAN DEN Berg (2008) and Gross (2011).

13 All the variables, how they are measured and data sources, are described in detail in Appendix II. 
value is used to avoid simultaneity problems. ${ }^{14}$ The average immigration rate for Canada is 0.033 and for the US 0.090 . The variations across occupation groups are quite large with a minimum of zero for both countries and a maximum of 0.219 for Canada, and 0.425 for the US (see Table 4). Not surprising both maximum values are reached in the manager categories, in 2001 for Canada and in 2007 for the United States.

Table 4: Statistical Characteristics of the Variables

\begin{tabular}{|c|c|c|c|c|}
\hline & Mean & Maximum & Minimum & S.D. \\
\hline \multicolumn{5}{|c|}{ Dependent variables } \\
\hline FLRate ${ }_{j i t}^{\mathrm{CH}}$ & .062 & 0.425 & 0 & 0.086 \\
\hline Canada & .033 & 0.219 & 0 & 0.044 \\
\hline United States & .090 & 0.425 & 0 & 0.107 \\
\hline \multicolumn{5}{|c|}{ Independent variables } \\
\hline Earn $_{i t}{ }^{C H}$ & 78,201 & 88,972 & 57,364 & 8,430 \\
\hline $\operatorname{Earn}_{j i t}(2005-\mathrm{US} \$)$ & 64,646 & 163,942 & 35,052 & 22,274 \\
\hline Canada & 70,907 & 163,942 & 43,962 & 27,390 \\
\hline United States & 58,385 & 89,948 & 35,052 & 12,866 \\
\hline $\operatorname{URUni}{ }^{C H}{ }_{t}$ & 2.36 & 4.50 & 1.18 & 0.76 \\
\hline$U R U n i_{j t}$ & 3.64 & 5.83 & 1.67 & 1.24 \\
\hline Canada & 4.69 & 5.83 & 3.68 & 0.61 \\
\hline United States & 2.59 & 4.61 & 1.67 & 0.68 \\
\hline LFUni ${ }_{t}{ }_{t}\left(\times 10^{3}\right)$ & 980.61 & $1,462.00$ & 707.10 & 215.12 \\
\hline$L F U n i_{j t}\left(\times 10^{3}\right)$ & $19,466.42$ & $45,634.00$ & $1,940.05$ & $17,015.60$ \\
\hline Canada & $3,013.28$ & $4,268.78$ & $1,940.05$ & 706.91 \\
\hline United States & $35,919.56$ & $45,634.00$ & $26,375.29$ & $5,999.97$ \\
\hline LFBord $_{t}\left(\times 10^{3}\right)$ & $3,861.10$ & $5,293.37$ & $2,774.84$ & 753.14 \\
\hline $\operatorname{LFEU}_{t}\left(\times 10^{3}\right)$ & $41,175.06$ & $56,781.22$ & $28,276.10$ & 8578.06 \\
\hline UnempEU $U_{t}\left(\times 10^{3}\right)$ & $3,787.79$ & $6,241.99$ & $2,820.66$ & 811.18 \\
\hline
\end{tabular}

a The immigration rate is defined as the ratio of immigrant flow in year $t$ and Swiss tertiary labour force in year $t-1$.

Sources: see variable definitions in Appendix II.

14 Also, the Swiss skilled labour force may be endogenous to the immigration flows if changes in policy have an impact on incentives to study for Swiss residents. The results of the Grangercausality test show that in this sample, the dependent variable does not Granger cause $L F U n i{ }^{C H}{ }_{t}$ $(\mathrm{F}$-statistics $=0.12, \mathrm{p}$-value $=0.89)$ and thus, endogeneity is unlikely. 
The explanatory variables representing individual maximisation are the log of real occupation-specific earnings and high education unemployment rates in the source countries $\left(\right.$ IEarn $\left._{j i t} ; U R U n i_{j i}\right)$ and in Switzerland $\left(\operatorname{lEarn}^{\mathrm{CH}}{ }_{i t} ; U R U n{ }^{\mathrm{CH}}{ }_{t}\right)$. Relatively higher earnings and lower unemployment among tertiary-educated people in Switzerland are expected to increase the flow of highly skilled foreigners as relative financial rewards and probabilities to find a job improve. The Swiss unemployment rate is expected to capture the labor market driven immigration policy (demand-side) rather than the perception by applicants of the job market (supply-side) since new immigrants must have a job contract.

Tertiary-educated labor forces in the source countries and in Switzerland $\left(I L F U n i_{j i} ; l L F U n i{ }_{t}{ }_{t}\right)$ are expected to have a positive sign in the traditional gravity model as bigger masses generate larger flows. In the context of brains, larger pools can be seen as proxies for professional networks. So, a larger skilled labor force at destination (i.e. Switzerland) can be seen as attractive for North Americans and can increase the flow of immigrants. However, larger networks at home for the same reason may decrease the incentive to migrate. In addition, the policy since 2002 that requires employers to choose among local candidates first would also decrease the flow of immigrants when the Swiss skilled labor force increases as employers have more choice domestically. Hence, because of the opposite effect from size (mass effect) and quality (network effect) of labor forces, the signs are indeterminate. Nevertheless, after 2002, the negative impact of the Swiss labor force through priority in hiring is likely to have increased.

The move to free mobility with the EU is tested in several different ways. First, a simple dummy variable (Policy 2002) with value 0 until 2002, 0.5 in 2002 and 1 afterwards is used to capture a fixed impact of the introduction of the new policy. The dummy variable is also interacted with the explanatory variables to evaluate potential changes in elasticities. Second, the impact of free mobility is measured through the sudden direct access to a much larger pool of skilled workers including not just residents of Switzerland but also residents of the European Union. Two variables are considered: The supply provided by the border countries $\left(\operatorname{LFBord}_{t}\right)$ and the supply provided by EU countries eligible to free mobility with Switzerland $\left(L F E U_{t}\right){ }^{15}$ The use of the supply from border countries only (i.e., Austria, France, Germany and Italy) is based on geographical closeness and on the sharing of languages with Switzerland, two characteristics likely to favour their

15 Unfortunately labor force statistics for six of the $15 \mathrm{EU}$ countries (Ireland, Luxemburg, Netherlands, Finland, Greece and Sweden) are not consistently available over the whole period. Together they represent less than 5\% of EU15 immigration since 2002 (European Commission, 2011). 
citizens within the new priority set-up for immigrants. Also, immigrant workers from these four countries represented more than $90 \%$ of the European annual inflow and $60 \%$ of total annual inflow. The measure is the weighted sum of university trained labor supplies from the four countries with the weights equal to the share of each country in the total length of the border with Switzerland. The supply from eligible EU countries is the weighted sum of university trained labor supply with the weights equal to the inverse of the distance between the capital of each country and Bern, the capital of Switzerland. Each weighted labor force is introduced with the constraint of equality of coefficients with the Swiss labor force after 2002 which is consistent with the fact that employers must consider them as perfect substitutes. ${ }^{16}$ Finally a dummy is also tested for the introduction of the dual recruiting system (Policy 1998) which recommended giving priority to Europeans. The model is first estimated in its basic form then various policy specifications are used to test the robustness of the results.

Because the time dimension of the sample is relatively long (20 years), before starting the estimations I ran unit-root tests. Table 5 shows that the hypothesis of individual unit roots can be rejected at $5 \%$. The case of a common unit-root process cannot be rejected but such a restriction is unlikely to be valid since hiring in different occupation categories has no reason to follow the same dynamics. Hence, the estimations are run in levels and spurious correlation is unlikely. The model is estimated by OLS even though migration rate is bounded at zero. In such context, zero-values represent information about the types of North American brains in demand in Switzerland and thus, cannot be eliminated. Since they do not represent censored data, estimations using Tobit are not considered appropriate. To avoid biased results and the possibility of negative estimated values, the estimations are done in log linear form such that the dependent variable is $\ln \left[(\right.$ flow +1$\left.) / L_{F U n i}{ }^{c h}{ }_{t-1}\right]$, even though the number of zeroes is small (14 observations).

Some robustness tests and various experiments with the policy dummy for the introduction of free mobility are presented in Table 6 . Note that the results of an $\operatorname{AR}(2)$ serial correlation test require the use of serial correlation robust standard errors. One of the concerns with the rather parsimonious basic specification is potential omitted variables. ${ }^{17}$ For example, the empirical literature on

16 Statistically, it is not possible to enter the European and the Swiss labor force measures separately because of high correlation (about 0.980 ; see Table A.II.1).

17 Part of the reason for using a parsimonious model lies in the fact that the two North American economies are very similar in terms of the distribution of residents' characteristics relevant to migration decision such as age or human capital intensity. 
Table 5: Unit Root Tests for Dependent Variable $\left(\right.$ IFLRate ${ }_{j i t}$ ) from 1990 to 2010

\begin{tabular}{lllll}
\hline & $\begin{array}{c}\text { Specification with } \\
\text { individual effects and } \\
\text { time trend (1 lag) }\end{array}$ & $\begin{array}{c}\text { Specification with } \\
\text { individual effects and } \\
\text { time trend (2 lags) }\end{array}$ \\
\hline $\begin{array}{l}\mathrm{H}_{0} \text { : there is a common unit-root process: } \\
\text { Levin, Lin \& Chu t (p-value) }\end{array}$ & -1.25 & $(0.10)$ & -0.52 & $(0.30)$ \\
\hline $\mathrm{H}_{0}$ : there is an individual unit-root process: & & & & \\
$\mathrm{Im}$, Pesaran \& Shin W-stat. (p-value) & -1.76 & $(0.039)$ & -2.67 & $(0.004)$ \\
ADF-Fisher Chi-sq. (p-value) & 63.74 & $(0.027)$ & 69.07 & $(0.009)$ \\
\hline
\end{tabular}

Source: see variable definitions in Appendix II.

migration flows shows that geographical distance (proxy for cost of moving) and cultural determinants such as common language or former colonial ties are important determinants of the flows (see Clark, Hatton, and Williamson, 2007; MAYDA, 2010). In column 1, the fixed-effect test shows a strong contribution of source-country non time-varying factors to the size of the individual occupation-category flow rates. These factors may include the geographical distance and the fact that French is a common national language in Canada and Switzerland. Another factor may be international transferability of skills; employers for some occupations may have a preference for applicants of a given source country because of perceived better compatibility of training with demand.

However, the fixed effect captures only mean effects and if time-varying source-country effects are not adequately taken into account, endogeneity translates into correlation between the fixed effect and the error terms (WoOldRIDGe, 2002, Chapter 10). So, in column 2, I introduce a time variable for each crosssection to control for possible source-country specific aggregate time-varying factors. They are not significant which is consistent with the fact that the Canadian and American economies are closely linked through high levels of bilateral trade flows. Also, this likely generates multi-collinearity as the value of the coefficients of the source-country labor force variable shifts substantially (even though it is still not significant) because it is trended.

In column 1 free mobility has a significant adverse effect on immigration flows from North America and results in column 3, confirm there is no significant difference in the average fall in inflow of brains from Canada and the United States in 2002-2003; also the recommendation by the government to give priority to Swiss and EU citizens in 1998 does not have a significant impact (column 4). 
Table 6: Immigration Rate from Canada and the United States to Switzerland (lFLRate ${ }_{j i t}$ )

\begin{tabular}{|c|c|c|c|c|c|c|}
\hline & $\begin{array}{l}\text { Fixed } \\
\text { Effect }\end{array}$ & $\begin{array}{l}\text { Time } \\
\text { trend }\end{array}$ & $\begin{array}{c}\text { Canada vs } \\
\text { US }\end{array}$ & $\begin{array}{c}\text { Dual } \\
\text { Recruiting }\end{array}$ & $\mathrm{EU}$ & Border \\
\hline & 1. & 2. & 3. & 4. & 5. & 6. \\
\hline \multirow[t]{2}{*}{$\operatorname{lEarn}_{i t}{ }_{i t}$} & 1.50 & 1.78 & 1.46 & 1.28 & 1.42 & 1.40 \\
\hline & $(1.8)$ & $(0.9)$ & $(0.8)$ & $(0.6)$ & $(0.7)$ & $(0.7)$ \\
\hline \multirow[t]{2}{*}{$\operatorname{lEarn}_{j i t}$} & 1.16 & .546 & 1.02 & 1.28 & 1.02 & 1.10 \\
\hline & $(2.0)^{*}$ & $(0.5)$ & $(1.0)$ & (1.2) & $(1.0)$ & $(1.1)$ \\
\hline \multirow[t]{2}{*}{$U R U n i{ }^{C H}{ }_{t}$} & -.090 & -.084 & -.087 & -.139 & -.091 & -.101 \\
\hline & $(2.8)^{* *}$ & $(2.9)^{* *}$ & $(2.9)^{* *}$ & (2.6) & $(3.0)^{* *}$ & $(3.2)^{* *}$ \\
\hline \multirow[t]{2}{*}{$U R U n i_{j t}$} & -.063 & -.079 & -.065 & -.057 & -.072 & -.066 \\
\hline & (1.5) & (1.6) & (1.4) & $(1.2)$ & $(1.6)$ & $(1.4)$ \\
\hline \multirow[t]{2}{*}{$\operatorname{lLFUni}{ }^{\mathrm{CH}}{ }_{t}$} & -1.69 & -1.22 & -1.23 & -1.91 & - & - \\
\hline & $(3.4)^{* *}$ & $(1.1)$ & (1.9) & $(2.3)^{*}$ & 1.59 & 1.41 \\
\hline \multirow[t]{2}{*}{$l L F U n i_{j t}$} & .690 & -2.41 & .269 & 1.34 & $(1.5)$ & $(1.4)$ \\
\hline & $(1.4)$ & $(0.9)$ & $(0.3)$ & (1.3) & -.499 & -.497 \\
\hline Policy 2002 & $\begin{array}{l}-.504 \\
(4.7)^{* *}\end{array}$ & $\begin{array}{l}-.551 \\
(3.8)^{* *}\end{array}$ & $\begin{array}{l}-.619 \\
(2.7)^{* *}\end{array}$ & $\begin{array}{l}-.469 \\
(3.1)^{* *}\end{array}$ & $(3.3)^{* *}$ & $(3.3)^{* *}$ \\
\hline Time & - & $\begin{array}{l}.070 \\
(0.6)\end{array}$ & - & - & - & - \\
\hline Canada $\times$ Time & - & $\begin{array}{l}.058 \\
(1.7)\end{array}$ & - & - & - & - \\
\hline Canada $\times$ Policy 2002 & - & - & $\begin{array}{l}.201 \\
(0.8)\end{array}$ & - & - & - \\
\hline Policy 1998 & - & - & - & $\begin{array}{l}-.246 \\
(1.3)\end{array}$ & - & - \\
\hline$l\left(L F U n i{ }_{t}{ }^{C H} \times L F E U_{t}\right)$ & - & - & - & - & $\begin{array}{l}-1.27 \\
(2.2)^{*}\end{array}$ & - \\
\hline$l\left(L F U n i{ }_{t}{ }^{C H} \times\right.$ LFBord $\left._{t}\right)$ & - & - & - & - & - & $\begin{array}{c}-1.24 \\
(2.3)^{*}\end{array}$ \\
\hline Adj. $R^{2}$ & 0.902 & 0.904 & 0.902 & 0.903 & 0.903 & 0.903 \\
\hline $\mathrm{N}$ & 22 & 22 & 22 & 22 & 22 & 22 \\
\hline $\mathrm{T}$ & 20 & 20 & 20 & 20 & 20 & 20 \\
\hline Schwarz & 1.616 & 1.617 & 1.622 & 1.619 & 1.603 & 1.605 \\
\hline $\begin{array}{l}\mathrm{F}(21,411): c_{j i}=c \\
\text { (p-value) }\end{array}$ & $\begin{array}{l}122.06 \\
(0.000)\end{array}$ & - & - & - & - & - \\
\hline
\end{tabular}

Notes: Serial correlation robust standard errors in parentheses. The residuals show serial correlation in an $\operatorname{AR}(2)$ process such that

$$
e_{j i t}=-\underset{(0.75)}{0.006}+\underset{(0.000)}{0.436} e_{j i t-1}+\underset{(0.001)}{0.174} e_{j i t-2} ;
$$

with absolute t-values in parentheses. ${ }^{*},{ }^{* *}$, significant at $5 \%, 1 \%$ respectively. Sources: see variable definitions in Appendix II. 
Hence, only legislated priorities have affected the inflow of North American brains. Finally, the 2002-policy, in addition to the impact effect, is modelled by augmenting the Swiss labor force with the two measures of the EU labor force alternatively (columns 5 and 6). In both cases, the variable is significant but the coefficients are smaller and weaker than for the Swiss labour force alone. Overall these results suggest that the introduction of free mobility has led to changes beyond a simple impact effect and the basic model is likely to be under-specified.

In Table 7 all elasticities are allowed to vary after 2002 and several hypotheses are tested.$^{18}$ In column 1 , the negative impact of Swiss unemployment embodying the condition of having a job contract does not vary after 2002; however, the gravity dynamics (i.e., Swiss and North American labour forces) does change.

In columns 2 to 4 alternative specifications for the new policy are tested and the results are robust. Before free mobility the network effect dominated even though it is statistically weak. An increase in skilled labor force in North America and in Switzerland (i.e., expansion of networks) attracted brains. After the introduction of free mobility with EU/EFTA, there is substitution with Swiss labor force and the European highly skilled labor force however it is measured. In column 2, Swiss and EU labor force are allowed to be perfect substitutes after 2002. The magnitude of the post-2002 change in substitution is given by the coefficient on the Swiss-EU labor force (-1.36 significant at 1\%). The weak attraction from Swiss skilled labor force before 2002 for North American brains is completely offset ${ }^{19}$ and growth in EU labor force lowers their inflow. Those are clear indications that employers have been following the priority rules in hiring. All the other results of the model pre- and post-2002 are stable with respect to column 1 except the coefficient on Swiss earning which is now positive, significant; so, North American brains after 2002 respond to financial incentives in their decision to come to Switzerland. Limiting the labor force to border countries generates similar results (column 3). This is not surprising since the border countries include three of the largest European economies and the simple correlation between the two measures is extremely high (0.998). Finally, rather than considering the whole European labor force as the potential pool of applicants for jobs in Switzerland, only unemployed Europeans are taken into account (column 4) implying that only the unemployed would be interested in working in Switzerland. Even though this is an extremely restrictive assumption, there is

18 Note that the impact effect is dropped from the specification because of its high correlation with the labor force variables that change very slowly over time.

19 The Wald-test hypothesis that the after-2002 effect cancels the basic effect is: $\mathrm{H}_{0}:(1.70-1.36)=0$ cannot be rejected; $\mathrm{p}$-value $=0.757$. 
a significant yet smaller elasticity ( 0.997 versus 1.36 for the whole labor force) probably because the unemployed are less diversified and may not fit the demand characteristics as well.

Because North American brains seem to care about network effects, I also test if the skilled labour force can be a proxy for quality of work environment (i.e. network). In column 5 , the source-country skilled labour force is weighted with innovations $[(1 /$ patent $) \times L F U n i]$. The results clearly show that when innovation intensity increases at home (when patent applications by residents increase), immigration from North America decreases but when the labor force increases, immigration increases. So there is a quality and a quantity effect and the magnitude did not change with free mobility but it is strongly significant. It must be noted that the traditional factors of the push/pull model have very weak impact on North American skilled flows to Switzerland except for Swiss income and unemployment rate which characterizes the demand-driven policy. These results are, however, consistent with the findings of a paper comparing semi-skilled and skilled immigrant workers from 49 countries to Switzerland between 2000 and 2004. When many more source countries are considered, very similar results are found for skilled migrants (see Gross and Sснмiтt, 2006). Interestingly, a study of low-skill and high-skill immigration to France from 63 countries between 1983 and 2000 also finds that only financial attractiveness of the destination country is relevant to skilled immigrants (see Gross and Schmitt, 2012). The strong influence of financial incentives is also identified by Docquier, Lohest, and MarFOUK (2006) for skilled immigrants to OECD countries. So high-skill migrants clearly do not respond to the same factors as low-skill migrants; their emphasis is on financial return to human capital and work environment.

The next two experiments (columns 6 and 7) consider whether the labor forces from the three regions (Europe, North America and Switzerland) were treated similarly when the legislation allowed employers to do so. In column 6, the European labor force is assumed to be considered perfect substitute for the Swiss labor force before and after 2002 because of the Government's recommendation about priorities in hiring in 1998. Before 2002, the effect is not significant and after 2002, the result hardly changes and there is substitution against North Americans in favour of Europeans and Swiss. So, European skilled workers were not considered equivalent to Swiss workers before 2002. In column 7, North American and European workers are allowed to be considered substitutes before 2002 and European and Swiss, after 2002. Again, only the policy change after 2002 is significant. It is interesting that in these two experiments, after 2002, Swiss unemployment shows a much stronger impact. So, these two experiments suggest that prior 2002, skilled workers from the three regions were considered distinct 







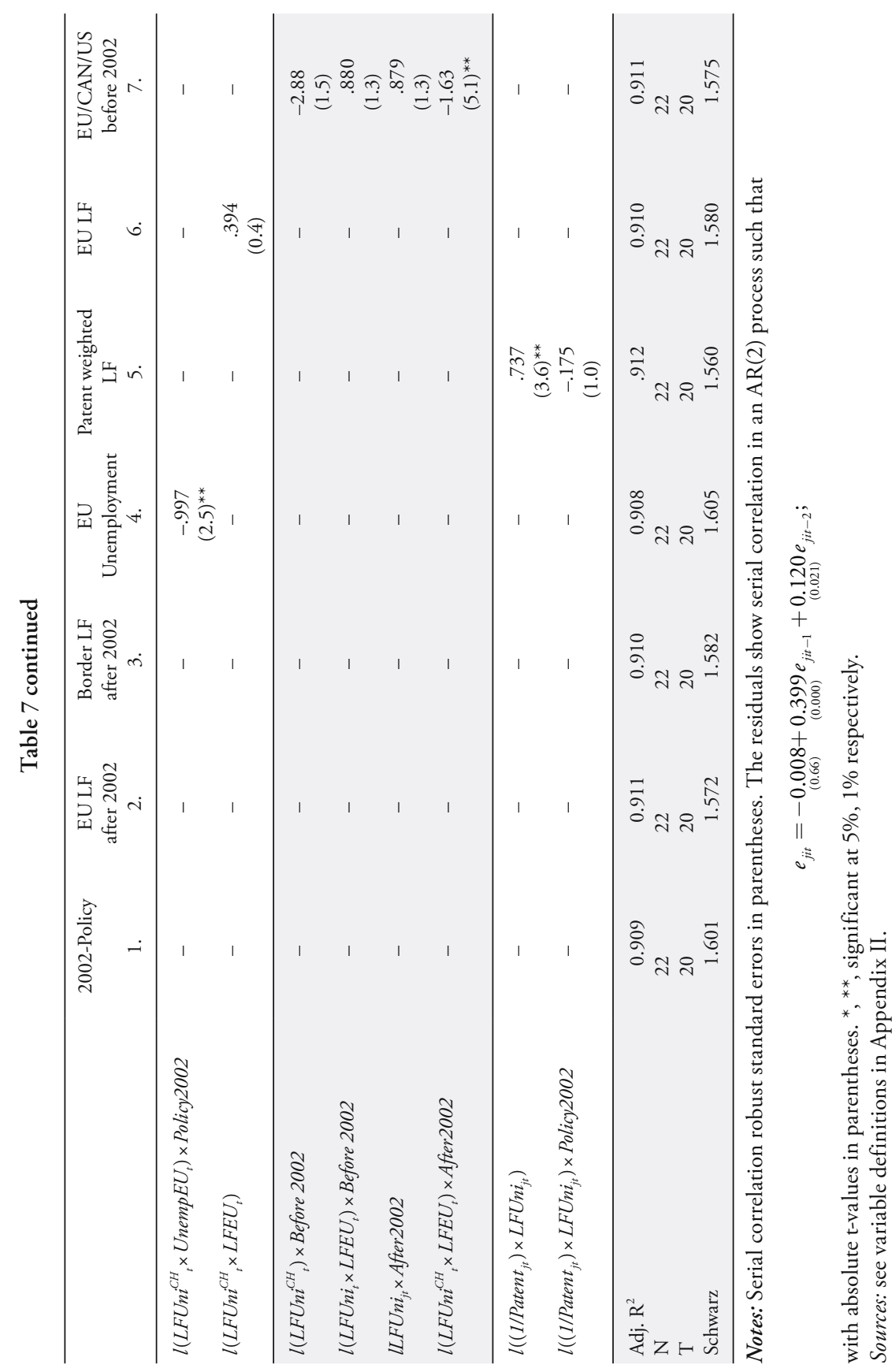


in hiring: Employers chose the most suitable high-skill candidates regardless of origin and only job availability was a constraint.

After 2002, Swiss and EU skilled workers had to be given priority over North Americans and their incentives changed. North Americans now expect a financial reward in terms of higher earnings and they pay much more attention to the stimulating work environment at home. In conclusion all the experiments are consistent with a significant substitution away from North American brains in favour of European and Swiss ones once hiring priorities became legislated.

\subsection{Future Economic Implications.}

One questions arising naturally from these results is: Does the evolution in the distribution of geographical origins of skilled immigrants to Switzerland have a potential impact on the country's future economic performance? While this question is not directly addressed through estimation, it is shown that occupations which matter for innovation have been adversely affected and this may have consequences for the future of the Swiss economy.

During the past decade evidence that a diaspora facilitates various economic links between their home and host countries has been growing. Expatriates have been shown to contribute to the expansion of trade between countries ( $\mathrm{RAUCH}$, 2001). This aspect appears to have been taken into consideration by Swiss legislators through the provision that priorities in hiring can be relaxed for economic reasons such as access to new markets or expansion of exports (CONFÉDÉRATION SuIsse, 2011a). There is also growing evidence that ethnic networks contribute to foreign direct investment (see for example Buch, Kleinert and Toubal, 2006; JaVORCiK et al., 2011) and recently a new argument has arisen: Ethnic networks can increase firms' competitiveness on world markets (FOLEY and KERR, 2011). Skilled expatriates can provide an information advantage (directly or indirectly) to firms that employ them which lowers entry barriers on foreign markets. FoLEY and KerR present evidence supporting the following three points: (1) Ethnic innovators have information advantage about the market and product in their home country and they can increase competitiveness of their firm abroad through better targeting; (2) firms with ethnic innovators are more likely to collaborate with inventors in their home countries associated with that ethnicity and gain information; (3) those gains in insight about foreign markets decrease the need for local partners in joint ventures which often generates additional costs. FolEY and KERR conclude that such evidence has clear implications for immigration policy. Consequently, if Swiss firms are constrained by law to hire skill immigrants mostly from the same region (i.e., the European Union) they might be 
penalized in their attempts to penetrate markets in other regions of the world. This could be a particularly important adverse effect of the immigration law given the rapid development of Asian economies and the fierce competitiveness among foreign firms to serve those markets. So, the next step is the estimation of the model for occupation categories of innovators (i.e., Engineers, E, Scientists, J, and Academics, L). ${ }^{20}$

Innovators have experienced smaller than average declines after 2002 but mixed evolutions. In Table 3, the average annual inflow of Canadian engineers increased by $42.9 \%$ while that from the US fell only by $5.4 \%$. Flows of academics decreased but their shares in total inflow grew: From $1.8 \%$ to $2 \%$ for Canada and from 2\% to $2.8 \%$ for the United States (see Figure 2). Scientists from both countries however experienced sharp declines.

The results of the estimations for the innovators are somewhat different from those for all skilled immigrants which is consistent with the fact that other professionals, such as executives for example, are likely to respond differently since they are not necessarily subjected to the new constraints. However, the new immigration legislation did have some adverse effects on innovators. ${ }^{21}$ In Table 8 , while there is no significant fixed impact of the legislation (column 1) there have been shifts in elasticities and the focus of discussion is column 4 with the more favorable Schwarz criteria.

There are three important points about the results. First, the impact of the state of the Swiss labor market on the probability to get a job is much larger after 2002 (i.e., the elasticity of the Swiss unemployment rate increases in absolute value from 0.170 to 0.944$)$. So the hiring of North American innovators has become much more sensitive to the state of the labor market while it was slightly above average before 2002. The mean tertiary-educated unemployment rate while still low has risen over the sample from $2.27 \%$ between 1990 and 2001 to $2.49 \%$ between 2002 and 2009; this may have caused a lasting decline in North American brain inflows. Second, substitution with Swiss brains is lowered ceteris paribus after 2002 as the impact of the Swiss labor force changed from 6.78 to 5.69. So, the new legislation did not benefit local innovators even though European applicants from border countries may be complement to North American (i.e. positive coefficient after 2002). One possible explanation is the high level of specialisation in

20 Foley and Kerr (2011) use engineers and scientists. Academics are added because in Switzerland they are major contributors to innovations especially at the EPFL and ETHZ.

21 The sample being much smaller (120 observations) the efficiency of the results is expected to be weaker so coefficients with a p-value around $6 \%$ (absolute t-value around 1.9) can still be considered to be significant in their impact. 
Table 8: Immigration of North American Innovators (Scientists, Engineers, Academics)

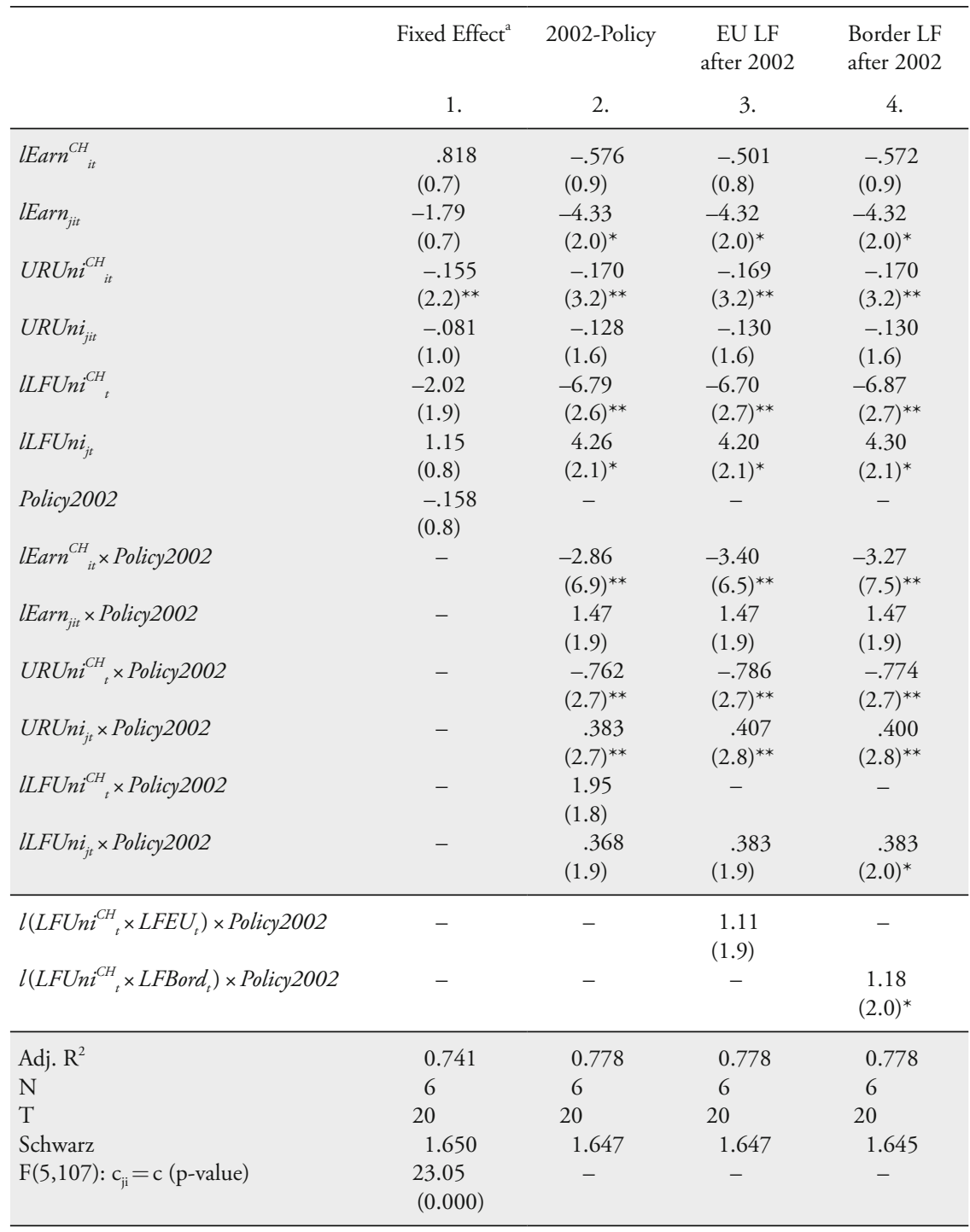

a Serial correlation robust standard errors in parentheses. The residuals show serial correlation in an $\operatorname{AR}(2)$ process such that

$$
e_{j i t}=-\underset{(0.80)}{0.010}+\underset{(0.08)}{0.181} e_{j i t-1}+\underset{(0.07)}{0.190} e_{j i t-2} ;
$$

with absolute t-values in parentheses. *, **, significant at 5\%, $1 \%$ respectively. Sources: see variable definitions in Appendix II. 
those occupations and the fact that such individuals from different regions with different training and experience are unlikely to be perfect substitutes. Finally, the influence of push factors changes after 2002 and the incentive to leave North America is higher when the market deteriorates but the financial incentive is somewhat weaker. Overall these results suggest that the new legislation has been beneficial neither to North Americans nor to Swiss innovators.

\section{Conclusion}

In 2002, Switzerland started to implement the free mobility agreement with the EU/EFTA member countries. Simultaneously, it established priorities in nationalities for hiring that restricted skilled immigration from the rest of the world. As a result, Swiss employers saw the pool of potential applicants increase $40-$ fold $^{22}$ but at the same time, they no longer had the freedom to hire the best of all potential candidates since they had to search sequentially across geographical areas. Clearly that policy affected Canadian and American brains (and probably also brains from Australia and New-Zealand) and their chance to obtain a job in Switzerland. Globally, the new policy, as expected, led to substitution in favour of Swiss and Europeans. But it has also had some undesirable side effects. North American high-skill migrants pay more attention to the stimulating innovative environment at home and earnings in Switzerland have become a significant determinant in their decision, increasing competitive pressure on Swiss employers.

The new policy may also penalise Swiss firms' competitiveness on world markets in the future. Since 2002, hiring of North American engineers, scientists and academics is much more dependent on the state of the Swiss labor market which exhibits higher average unemployment. So, increased volatility over the business cycle and a possible negative trend in unemployment may have adverse consequences for flows of non-European high-skill people in addition to the more restrictive policy. Growing evidence on the role of ethnic innovators in stimulating links between their home and host countries hints at the fact that less geographical heterogeneity among skilled immigrants may be costly to Swiss firms as they want to enter world markets. This effect seems particularly relevant for Switzerland as between 2004 and 2006 the country had the highest proportion of patent applications with co-inventors located in the European Union among OECD countries (OECD, 2009, Table 4.1). Thus, by raising barriers on hiring

22 The factor is computed using the mean of weighted EU labor force by the mean Swiss labor force with tertiary education. 
from North America and other regions of the world such as Asia, the new legislation may have decreased the possibility of similar collaboration with innovators from those regions and thereby decrease firms' competitiveness on those markets.

In conclusion, the problem is not too many Europeans as nationalists argue but rather it might be too much homogeneity in regions of origin of skilled immigrants. This is a first evaluation of the impact of free mobility with the EU on brain diversity; clearly the question should be investigated further especially at a more disaggregated level and in conjunction with international research cooperation and foreign direct investment.

\section{Appendix I}

The 11 categories of occupations for skilled immigrant workers are based on the American classification (USDJINS, 2002). ISCO codes up to 4 digits were used to determine the components of the occupation categories.

Table A.I.1: Occupation Categories

\begin{tabular}{|c|c|c|c|}
\hline \multicolumn{2}{|c|}{ Category/Occupation Titles } & \multirow{2}{*}{$\frac{\text { ISCO Code }}{2141 \& 2148}$} & \multirow{2}{*}{$\begin{array}{l}\text { Short name } \\
\begin{array}{l}\text { Architects and } \\
\text { related specialists }\end{array}\end{array}$} \\
\hline A & $\begin{array}{l}\text { Architects, cartographers, surveyors, and urban or land } \\
\text { use planners. }\end{array}$ & & \\
\hline B & $\begin{array}{l}\text { Administrative officers, bookkeepers, clerks, financial } \\
\text { and investment analysts, insurance underwriters, market- } \\
\text { ing and sales personnel, secretaries (except legal and med- } \\
\text { ical), securities agents, investment dealers, and brokers. }\end{array}$ & $\begin{array}{l}340-343 \& \\
400-422\end{array}$ & $\begin{array}{l}\text { Commercial } \\
\text { and financial } \\
\text { technicians }\end{array}$ \\
\hline $\mathrm{C}$ & $\begin{array}{l}\text { Kindergarten, elementary school and secondary school } \\
\text { teachers, vocational and educational counselors. }\end{array}$ & $232-235$ & Teachers \\
\hline $\mathrm{D}$ & $\begin{array}{l}\text { General practitioners and family physicians, other } \\
\text { professional occupations in health diagnosing and } \\
\text { treating, specialist physicians (including opticians, } \\
\text { dentists, podiatrists), and veterinarians. }\end{array}$ & $222 \& 3224$ & Physicians \\
\hline $\mathrm{E}$ & Engineers. & $2142-2147$ & Engineers \\
\hline $\mathrm{F}$ & $\begin{array}{l}\text { Corporate managers, managers of small enterprises, } \\
\text { and senior officials of organizations. }\end{array}$ & $100-131$ & Managers \\
\hline
\end{tabular}




\begin{tabular}{llll}
\hline Category/Occupation Titles & ISCO Code & Short name \\
\hline G $\begin{array}{l}\text { Air pilots; flight engineers; flying instructors; air traf- } \\
\text { fic control and related occupations; ambulance attend- } \\
\text { ants and other paramedical occupations; audiologist and } \\
\text { speech language pathologists; elementary and second- } \\
\text { ary school teachers' assistants; engineering inspectors and } \\
\text { regulatory officers; dieticians and related occupations; } \\
\text { life science and health (except nursing) technicians and } \\
\text { associate professionals; pharmacists, physiotherapists and } \\
\text { related associate professionals; physical and engineering } \\
\text { science operators, technicians, and technologists. }\end{array}$ & $\begin{array}{l}\text { Health } \\
\text { and science } \\
\text { technicians }\end{array}$ & \\
\hline H & $\begin{array}{l}\text { Archivists; librarians; artistic, entertainment and sport } \\
\text { associate professionals; business professionals (including } \\
\text { accountants, specialists in HR); counselors (except edu- } \\
\text { cational); journalists, editors, reporters, public relations, } \\
\text { announcers; law professionals (including paralegals); } \\
\text { religious professionals; social scientists; social workers; } \\
\text { translators, terminologists, interpreters, writers; creative } \\
\text { or performing arts. }\end{array}$ & $346-348$ & $\begin{array}{l}\text { Social scientists, } \\
\text { and humani- } \\
\text { ties related } \\
\text { professionals }\end{array}$ \\
$\begin{array}{l}\text { Computer programmers and developers, information } \\
\text { system analysts and consultants, mathematicians, } \\
\text { statisticians, actuaries, and web designers. }\end{array}$ & $212-213$ & IT professionals \\
\hline $\begin{array}{l}\text { Natural scientists and physical scientists. } \\
\text { L }\end{array}$ & $\begin{array}{l}\text { College and vocational instructors, post-secondary teach- } \\
\text { ers, and research assistants and university professors. }\end{array}$ & 231 \\
\hline
\end{tabular}




\section{Appendix II: Definitions of Variables}

The matching of skill definitions across skill-specific variables is given in Table A. II. 2 .

\begin{tabular}{|c|c|}
\hline lFLRate $_{j i t}^{C H}$ & $\begin{array}{l}\text { Log of the (flow }+1) \text { of skilled labor from source country } j(j=1 \text { to } 2) \text { in occu- } \\
\text { pation category } i(i=1 \text { to } 11) \text { to Switzerland }(C H) \text { during year } t(t=1990 \text { to } \\
\left.2010) \text { as a share of the tertiary educated labor force in Switzerland ( } L F U n i^{C H}\right) \\
\text { at time } t-1 \text { (ODM, various years). }\end{array}$ \\
\hline Earn $_{i t}^{C H}$, Earn $_{j i t}$ & $\begin{array}{l}\text { Earnings in Switzerland and source country j, occupation category } i \text {, at time } t \text {. } \\
\text { In Canada, log of annual earnings of individuals by NOC-S in } 2005 \text {-constant } \\
\text { dollars (SLID, Statistics Canada, 2011); sub categories are computed from } \\
\text { ratio of that category to overall from } 1995 \text {-Census (Statistics Canada, 2008) } \\
\text { converted in } 2005 \text { US } \$ \text { at the annual } 2005 \text { exchange rate (Bank of Canada, } \\
\text { 2011). In the United States, total private weekly private average earnings in } \\
2005 \text { dollars (US BLS, 2011a) weighted with ratio of occupational hourly } \\
\text { compensation to average in } 1997 \text { (US BLS, 1999). In Switzerland, gross nomi- } \\
\text { nal annual revenue by ISCO 2-digit level (ESPA, Table 3.4.3.1., OFS, 2011), } \\
\text { corrected with CPI (Table 5.2.1., OFS, 2011) in } 2005 \text { US } \$ \text { at the average of } \\
\text { monthly } 2005 \text { exchange rate (SNB, 2011); the missing income observations } \\
\text { for } 1990 \text { were built using average growth rates over the following decade. }\end{array}$ \\
\hline$L_{F B o r d}, L F E U_{t}$ & $\begin{array}{l}\text { Weighted average of tertiary educated labor force from } 4 \text { border countries } \\
\text { of Switzerland (France, Italy, Germany, Austria) and from } 9 \text { of the EU15 } \\
\text { countries (border countries + United Kingdom, Belgium, Spain, Portu- } \\
\text { gal, Denmark). The tertiary educated labor force (LF) is computed from } \\
\text { employment (E) and unemployment rate (UR) for tertiary educated such } \\
\text { that LF =E/ (1-UR) for people aged } 15 \text { to } 64 \text { with tertiary education (i.e., } \\
\text { ISCED 5-6, ISCED 1997, European Commission, 2011). The missing obser- } \\
\text { vations for 1990-1991 for Italy and Germany, 1990-1992 for France and } \\
\text { 1990-1994 for Austria are built using average growth rates in the tertiary } \\
\text { educated labor force over the available period. In the case of the border coun- } \\
\text { tries, the weights are the share of each country's border length in the total } \\
\text { border of Switzerland (www.switzerlandonline.org/). In the case of the EU } \\
\text { countries, the weights are the inverse of the distance in kilometers between } \\
\text { the Swiss capital city, Bern, and the capital city of each country (www.map- } \\
\text { crow.info). }\end{array}$ \\
\hline$L F U n i_{t}^{C H}, L F U n i_{j t}$ & $\begin{array}{l}\text { Labor force aged between } 15 \text { and } 65 \text { years old with a university degree in } \\
\text { Canada (Statistics Canada 2011). In the United States, labor force with a } \\
\text { bachelor's degree and higher, } 25 \text { years and over; the missing labor force num- } \\
\text { bers, 1990-91 are extrapolated using the average growth rate for the period } \\
\text { 1992-2000, (US BLS, 2011b). In Switzerland, labor force with tertiary edu- } \\
\text { cation (university and advanced professional education; ESPA, OFS, 2011); } \\
\text { the missing observations for } 1990 \text { are built using average growth rates over } \\
\text { the available period. }\end{array}$ \\
\hline Patent $_{j t}$ & $\begin{array}{l}\text { Number of patent applications by residents in Canada and the US (WB, } \\
\text { 2012). }\end{array}$ \\
\hline
\end{tabular}




\section{Table A.I.1 continued}

Policy 2002 Dummy with value 0.5 for 2002, 1 from 2003 to 2010 and 0 otherwise; measures the introduction of free mobility with EU and EFTA.

Policy 1998 Dummy with value 1 from 1999 to 2010 and 0 otherwise; measures the circle policy with recommendation to give priority to EU workers (i.e., dual recruiting) after November 1998.

UnempEU $U_{t} \quad$ Weighted unemployment for tertiary educated people in 9 of the EU15 countries computed from E, LF and UR (see LFBord $t_{t}, L F E U_{t}$ ).

$U R U n i{ }^{C H}{ }_{t}, U R U n i_{j t}$ Unemployment rate in destination and source country $j$, at time $t$. In Canada, unemployment rates both sexes, university degree, 15 years and over (Statistics Canada, 2011, Table v2627998). In the United States, unemployment rate for tertiary level of education computed from labor force and employment level data 25 years and over (US BLS, 2011b). In Switzerland, unemployment rate for tertiary level of education computed from labor force and unemployment level data (OFS, 2011).

Table A.II.1: Correlations between Independent Variables

\begin{tabular}{|c|c|c|c|c|c|c|c|}
\hline & $\operatorname{lEarn}_{i t}{ }^{C H}$ & LEarn $_{j i t}$ & $U R U n i_{i t}{ }^{C H}$ & $U R U n i_{j i t}$ & lLFUni ${ }_{t}{ }_{t}$ & $l L F U n i_{j t}$ & lLFBorder $_{t}$ \\
\hline lEarn $^{C H}{ }_{i t}$ & 1 & & & & & & \\
\hline LEarn $_{j i t}$ & 0.438 & 1 & & & & & \\
\hline$U R U n i{ }_{t}{ }_{t}$ & 0.016 & -0.021 & 1 & & & & \\
\hline$U R U n i_{j t}$ & 0.042 & 0.216 & 0.072 & 1 & & & \\
\hline $\operatorname{lLFUni}{ }_{t}{ }_{t}$ & 0.023 & 0.168 & 0.120 & -0.048 & 1 & & \\
\hline$l L F U n i_{j t}$ & 0.003 & -0.253 & 0.025 & -0.859 & 0.157 & 1 & \\
\hline lLFBorder $_{t}$ & 0.015 & 0.176 & 0.111 & -0.091 & 0.983 & 0.160 & 1 \\
\hline ILFEU $U_{t}$ & 0.015 & 0.174 & 0.145 & -0.098 & 0.978 & 0.161 & 0.998 \\
\hline
\end{tabular}









\section{References}

Arthur D. Little (Switzerland) Ltd (2009), Headquarters on the MoveBenchmarking of Global and Regional Headquarters in Switzerland, November, Zurich.

Bank of Canada (2011), Annual Average Exchange Rates, Financial Markets Department, Ottawa.

Beine, Michel, Frédéric Docquier, and Hillel Rapoport (2001), "Brain Drain and Economic Growth: Theory and Evidence", Journal of Economic Development, 64, pp. 275-289.

Borjas, George J. (1987), "Self-Selection and the Earnings of Immigrants", American Economic Review, 77(4), pp. 531-553.

Buch, Claudia M., Jorn Kleinert, and Farid Toubal (2006), "Where Enterprises Lead, People Follow? Links between Migration and FDI in Germany", European Economic Review, 50(8), pp. 2017-2036.

Clark, Ximena, Timothy J. Hatton, and Jeffrey G. Williamson (2007), "Explaining U.S. Immigration 1971-1998", The Review of Economics and Statistics, 89(2), pp. 359-373.

Commander, Simon, Marij Kangasniemi, and L. Alan Winters (2004), "The Brain Drain: Curse or Boon? A Survey of the Literature", in Challenges to Globalization: Analyzing the Economics, Robert E. Baldwin and L. Alan Winters, eds., NBER Conference Report, pp. 235-278, Chicago: University of Chicago Press.

Confédération Suisse (2011a), «Loi fédérale sur les Etrangers (LEtr) du 16 décembre 2005», Recueil systématique du Droit fédéral, RS 142.20, Bern, www. admin.ch/ch/f/as/2007/5437.pdf, accessed August $18^{\text {th }}$.

CONFÉdÉration SuISSE (2011b), «Ordonnance sur l'introduction progressive de la libre circulation des personnes entre, d'une part, la Confédération suisse et, d'autre part, la Communauté européenne et ses Etats membres, ainsi qu'entre les Etats membres de l'Association européenne de libre-échange (OLCP) du 22 mai 2002", Recueil systématique du Droit fédéral, RS 142.203, Bern, www. admin.ch/ch/f/as/5437.pdf, accessed August $18^{\text {th }}$.

DFJP \& ODM, Département fédéral de Justice et Police \& Office fédéRal des Migrations (2011a), Séjourner en Suisse au titre d'une autorisation, Fact Sheet, Bern, http://www.bfm.admin.ch/content/dam/data/migration/schweiz___eu/personenfreizuegigkeit/factsheets/fs-bew-aufenthalt-f.pdf, accessed August $18^{\text {th }}$.

DFJP \& ODM (2011b), Libre circulation des personnes avec l'Union européenne, Fact Sheet, Bern, http://www.bfm.admin.ch/content/dam/data/migration/ 
schweiz___eu/personenfreizuegigkeit/factsheets/fs-uebersicht-fza-f.pdf, accessed August $18^{\text {th }}$.

Docquier, Frédéric, Olivier lohest, and Abdeslam Marfouk (2006), "What Determines Migrants' Destination Choice?", mimeo, IRES, Department of Economics, Université Catholique de Louvain, Belgium.

Docquier, Frédéric, and Abdeslam Marfouk (2005), "International Migration by Education Attainment 1990-2000", Release 1.1., The World Bank Policy Research Paper 3382/2004 (updated March 2005), Washington, DC. European Commission (2011), EUROSTAT, electronic database, Brussels. http://epp.eurostat.ec.europa.eu/portal/page/portal/statistics/search_database, accessed July $19^{\text {th }}$.

Foley, C. Fritz, and William R. Kerr (2011), "Ethnic Innovation and U.S. Multinational Firm Activity", Working Paper 12-006, Harvard Business School.

Gross, Dominique M. (2011), "High-skill Migration to Canada and Switzerland: Retention, Attraction and Competition with the United States through Policy”, Working Paper 11-03, Metropolis British Columbia, Centre of Excellence for Research on Immigration and Diversity.

Gross, Dominique M. (2006), "Immigration Policy and Foreign Population in Switzerland”, The World Bank Policy Research Working Paper 3853, Washington, DC.

Gross, Dominique M., and Nicolas Schmitt (2012), "Low- and High-skill Migration Flows: Free Mobility versus other Determinants", Applied Economics, 44(1-3), pp. 1-20.

Gross, Dominique M., and Nicolas Schmitt (2006), "Skilled Immigration Flows and Free Mobility in France and Switzerland", Skills Research Initiative, Working Paper 2006 D-23, Human Resources and Social Development Canada, Industry Canada, Social Science and Humanities Research Council, Ottawa.

Harris, John R., and Michael Todaro (1970), "Migration, Unemployment and Development: A Two-Sector Analysis”, American Economic Review, 60(1), pp. 126-142.

Helliwell, John F. (1997), "National Borders, Trade and Migration", Pacific Economic Review, 2(3), 165-185.

HRDC, Human Resources Development Canada (2006), National Occupational Classification, Ottawa. http://www23.hrdc-drhc.gc.ca/2001/e/groups/ index.shtml.

ilO, International Labour Organisation (1990), International Standard Classification of Occupations: ISCO-88, Geneva. 
IMD (2011), World Competitiveness Yearbook, electronic database, Lausanne. Isard, Walter (1998), "Gravity and Spatial Interaction Models", in Methods of Interregional and Regional Analysis, Walter Isard, Iwan J. Azis, Matthew P. Drennan, Ronald E. Miller, Sidney Saltzman, and Erik Thorbecke, eds, chap. 6, pp. 243-279, Aldershot, UK: Ashgate.

Ivlevs Artjoms, and James De Melo (2008), "FDI, the Brain Drain and Trade: Channels and Evidence", Development Studies Working Papers No 261, Centro Studi Luca d'Agliano, University of Milan, October.

Javorcik, Beata S., ÇaĞlar Özden, Mariana Spatareanu, and Cristina NeAgu (2011), "Migrant Networks and Foreign Direct Investment", Journal of Development Economics, 94, pp. 231-241.

Karemera, David, Victor Iwuagwu Oguledo, and Bobby Davis (2000), "A Gravity Model Analysis of International Migration to North America", Applied Economics, 32(13), pp. 1745-1755.

Lewer Joshua J., and Hendrik Van den Berg (2008), "A Gravity Model of Immigration", Economics Letters, 99, pp. 164-167.

Mayda, Anna Maria (2010), "International Migration: A Panel Data Analysis of the Determinants of Bilateral Flows", Journal of Population Economic, 23(4), pp. 1249-1274.

Muller, Henry (2010), “Too Many Foreign Profs in Swiss Universities?”, Reflex Science + Technology + Innovation, May, 78-79, http://www.largeur. $\mathrm{com} /$ ? $\mathrm{p}=3139$

ODM, Office fédéral des Migrations (Various years), Registre central des Etrangers, Bern.

OECD, Organisation for Economic Co-operation and Development (2009), OECD Science, Technology and industry scoreboard. 2009, Paris.

OFS, Office fÉdÉral de la Statistique (2011), Encyclopédie statistique de la Suisse, electronic database, Neuchâtel, www.bfs.admin.ch/bfs/portal/fr/ index.html

OFS (2009), Démos. Informations démographiques, Newsletter No 4, December, Neuchâtel.

OSEC Business Network, Swiss American Chamber of Commerce and McKinsey \& Company (2008), Asian Headquarters in Europe. A Strategy for Switzerland, November.

Rauch, James E. (2001), "Business and Social Networks in International Trade", Journal of Economic Literature, 39(4), pp. 1177-1203.

SjaAstad, Larry A. (1962), "The Costs and Returns of Human Migration", Journal of Political Economy, 70(5), pp. 80-93. 
SNB, Swiss National Bank (2011), Financial Market Data, electronic database, Zurich. www.snb.org/statistiks.

Statistics Canada (2011), CANSIM, electronic database. Ottawa.

Statistics Canada (2008), 1996-Census standard data products, Earnings of Canadians, Ottawa, www12.statcan.ca/English/census)1/products/standard/ themes.

Swiss American Chamber of Commerce and Boston Consulting Group (2008), Creative Switzerland? Fostering an Innovation Powerhouse, Zurich, December.

US BLS, United States Bureau of Labor Statistics (2011a), Current Employment Statistics Survey, electronic database, Washington, DC, http://data.bls. gov/data.

US BLS (2011b), Current Population Survey, electronic database, Washington, DC, http://data.bls.gov/data.

US BLS (1999), National Compensation Survey: Occupational Wages in the United States, 1997, US Department of Labor, Washington, DC, September.

US DJinS, United States Department of Justice, Immigration and Naturalization Services (2002), Statistical Yearbook of the Immigration and Naturalization Service, 2000, Washington, DC: U.S. Government Printing Office.

WB, World Bank (2012), World Development Indicators, electronic database, Washington, DC.

Wooldridge, Jeffrey M. (2002), Econometric Analysis of Cross Section and Panel Data, Cambridge, Mass.: The MIT Press.

\section{SUMMARY}

In 2002, Switzerland started to implement free mobility with the European Union and simultaneously immigration rules for citizens from the rest of the world became more stringent. Only skilled workers could be hired from third countries and employers had to give priority in hiring to Swiss and European skilled applicants. This paper shows that the new legislation has strongly adversely affected the size of high-skill immigration from North America. Also, incentives to leave those countries have changed as North Americans are more inclined to consider home professional networks and financial opportunities. The consequence is less geographical heterogeneity in immigrants which may decrease Swiss firms' ability to gain information about non-European markets and increase their entry cost into those markets. 